\title{
Effects of Combined Amendments on Growth and Heavy Metal Uptake by Pakchoi (Brassica chinensis L.) Planted in Contaminated Soil
}

\author{
Zhangwei Li*, Weibo Zhu, Xiaoyun Guo \\ Department of Chemistry, Hanshan Normal University, Chaozhou 521041, China \\ Received: August 25, 2015 \\ Accepted: September 23, 2015
}

\begin{abstract}
Remediating soils with heavy metals contamination is a significant challenge. This study investigated the co-remediation effect when paired soil amendment mixtures were used to treat soil contaminated by $\mathrm{Pb}$, $\mathrm{Cd}$, and $\mathrm{Zn}$. The three mixed amendments are:

1) micro particle hydroxyapatite (mHAP) and humic acid

2) nano particle hydroxyapatite (nHAP) and humic acid

3) sepiolite and humic acid.

Co-remediation with these amendment pairs was compared with remediation using mHAP, nHAP, sepiolite, and humic acid on their own. Using pot experiments, the $\mathrm{Pb}, \mathrm{Cd}$, and $\mathrm{Zn}$ fractions of sequential extraction in the contaminated soil and the concentration of $\mathrm{Pb}, \mathrm{Cd}$, and $\mathrm{Zn}$ in shoots and roots of pakchoi were measured by the use of inductively coupled plasma optical emission spectrometry (ICP-OES). Mixed and single treatments were applied to investigate the differences in remediation effects for the three metals. Study results showed that the co-application of amendments more effectively reduced $\mathrm{Pb}, \mathrm{Cd}$, and $\mathrm{Zn}$ in pakchoi shoots and roots than with single amendments alone. Co-remediation with the amendment mixtures reduced non-residual fractions of $\mathrm{Pb}, \mathrm{Cd}$, and $\mathrm{Zn}$ in the contaminated soil more than single amendment supplements. Furthermore, the co-application of $30 \mathrm{~g} \cdot \mathrm{kg}^{-1}$ micro particle hydroxyapatite with $20 \mathrm{~g} \cdot \mathrm{kg}^{-1}$ humic acid was most effective in reducing the amount of $\mathrm{Pb}, \mathrm{Cd}$, and $\mathrm{Zn}$ absorbed by the pakchoi and the non-residual fraction of $\mathrm{Pb}, \mathrm{Cd}$, and $\mathrm{Zn}$ in the contaminated soil. Results suggest that co-remediation using $30 \mathrm{~g} \cdot \mathrm{kg}^{-1}$ micro particle hydroxyapatite with $20 \mathrm{~g} \cdot \mathrm{kg}^{-1}$ humic acid may be an efficient method to remediate $\mathrm{Pb}, \mathrm{Cd}$, and $\mathrm{Zn}$ in heavy metals-contaminated soil.
\end{abstract}

Keywords: heavy metal, soil contamination, nano particle hydroxyapatite, sepiolite, humic acid

\section{Introduction}

Many researchers have engaged in studies about soils contaminated with heavy metals, because of the threats posed to ecosystems and human health. Many remediation

*e-mail: 99094001@163.com methods - such as phytoremediation, immobilization, chemical washing, and mechanical separation - have been successfully applied to remediate this type of contamination [1-3]. Applying soil amendments to immobilize heavy metals is a promising technology to meet the requirements for environmentally friendly, convenient, and cost-effective remediation operations $[4,5]$. Supplemental soil amend- 
Table 1. Basic soil properties.

\begin{tabular}{|c|c|c|c|c|c|c|c|}
\hline \multirow{2}{*}{$\mathrm{pH}$} & \multirow{2}{*}{$\begin{array}{c}\text { Organic matter } \\
\left(\mathrm{g} \cdot \mathrm{kg}^{-1}\right)\end{array}$} & \multicolumn{3}{|c|}{ Available $\left(\mathrm{mg} \cdot \mathrm{kg}^{-1}\right)$} & \multicolumn{3}{|c|}{ Total $\left(\mathrm{mg} \cdot \mathrm{kg}^{-1}\right)$} \\
\cline { 3 - 8 } & & $\mathrm{N}$ & $\mathrm{P}$ & $\mathrm{K}$ & $\mathrm{Pb}$ & $\mathrm{Cd}$ & $\mathrm{Zn}$ \\
\hline 6.48 & 30.7 & 43.9 & 32.3 & 69.0 & $1,139.2$ & 7.54 & 321.9 \\
\hline
\end{tabular}

ments reduce the solubility and bioavailability of heavy metals in contaminated soil, protecting plants in that environment. Therefore, identifying cost-effective amendments to remediate heavy metals in contaminated soil is of increasing importance.

Many natural materials such as limestone, zeolite, hydroxyapatite, sepiolite, palyorskite, and red mud have been reported to effectively remediate soil contaminated with heavy metals [6-10]. Among these amendments, hydroxyapatite is considered one of the most effective natural materials in immobilizing heavy metals in soil $[11,12]$. With the rapid development of nanotechnology, nanoparticles of hydroxyapatite has been effectively applied to immobilize and remediate toxic heavy metals in soil [13-15]. However, until now little research has been done comparing the effect of nano- and micro-hydroxyapatite (nHAP and mHAP) in remediating heavy metals-contaminated soils. It was hypothesized that nHAP was superior to mHAP in immobilizing heavy metals in soil due to its smaller particle size, larger surface area, and more chemical activity sites [8].

Sepiolite is another chemical soil amendment that has been considered as a useful remediation agent for immobilizing heavy metals in soils $[1,7,9]$. Sun reported that in cadmium (Cd)-contaminated soils, a supplemental application of $10 \mathrm{~g} \cdot \mathrm{kg}^{-1}$ sepiolite led to a $58.5-65.5 \%$ increase in spinach shoot biomass, compared with the control group. Moreover, the $\mathrm{Cd}$ concentrations in the spinach shoots and roots decreased by $38.4-59.1 \%$ and $12.6-43.6 \%$, respectively, in contrast to the control [7].

The other chemical soil amendment attracting extensive attention is organic matter, which has the ability to transform metals to form stable complexes with organic legends $[6,16]$. Humic acids, the most abundant fraction of decomposed organic matter, has been a focus of some research, including studies that have found that humic acids could immobilize toxic heavy metal in soils by redistributing them into less available forms $[17,18]$.

Although past research has evaluated the effect of natural materials and humic acid on soil contaminated with heavy metals, applying these materials together has not been done previously. Therefore, this study's objectives were to:

1) examine the effects of nHAP and mHAP on the immobilization of $\mathrm{Pb}, \mathrm{Cd}$, and $\mathrm{Zn}$ in contaminated soil

2) evaluate the effectiveness of nHAP, mHAP, seolite, and humic acid as amendments to co-remediate $\mathrm{Pb}-, \mathrm{Cd}-$, and $\mathrm{Zn}$-contaminated soil

3) investigate the effectiveness of different chemical treatments on the uptake of $\mathrm{Pb}, \mathrm{Cd}$, and $\mathrm{Zn}$ by pakchoi (Brassica chinensis L.).

\section{Material and Methods}

\section{Soil Sample Properties}

The soil samples used for this study (contaminated with $\mathrm{Pb}, \mathrm{Cd}$, and $\mathrm{Zn}$ ) were collected from a suburban area in Shantou City, Guangdong Province, China. The heavy metals in the soil are assumed to have come from local smelting industries. After being air-dried, the soil samples were ground and passed through a $2 \mathrm{~mm}$ sieve for pot experiments. Soil pH (soil-to-water ratio of 1:2.5) was determined using a combination $\mathrm{pH}$ electrode. Soil organic matter was measured using wet digestion with $\mathrm{K}_{2} \mathrm{Cr}_{2} \mathrm{O}_{7}$ and $\mathrm{H}_{2} \mathrm{SO}_{4}$. Total $\mathrm{Pb}, \mathrm{Cd}$, and $\mathrm{Zn}$ in the soil was determined using inductively coupled plasma optical emission spectrometry (ICP-OES), following $\mathrm{HF}-\mathrm{HNO}_{3}-\mathrm{HClO}_{4}$ digestion procedures [19]. Available N, P, and K were analyzed using standard methods recommended by $\mathrm{Lu}$ [19]. Table 1 provides the soil chemical characteristics and $\mathrm{Pb}, \mathrm{Cd}$, and $\mathrm{Zn}$ concentrations.

\section{Pot Experimental Design}

The pot experiment was conducted using 15 treatments, with four replicates per treatment level (Table 2). Soil samples $(3.0 \mathrm{~kg}$ each) were placed into individual plastic pots. Before adding treatments, $6.0 \mathrm{~g} \cdot$ pot $^{-1}$ soil as $\mathrm{NH}_{4} \mathrm{NO}_{3}$ and 6.0 $\mathrm{g} \cdot$ pot $^{-1}$ soil potassium were added as fertilizers. Soil amendments were thoroughly mixed with soil samples after being air-dried and passed through a 60-mesh sieve. Amendments included nano particle hydroxyapatite (nHAP), micro particle hydroxyapatite (mHAP), sepiolite, and humic acid. The nHAP and mHAP were bought from the Emperor Company in China, and the sepiolite and humic acid were bought from Guangzhou Chemical Reagent Company in China. Deionized water was used to maintain $20 \%$ of the soil water-holding capacity. The soil was left to equilibrate for 30 days before planting the pakchoi (Brassia chinensis L.). Ten pre-germinated seeds were sown in each pot. Seven days after seedlings emerged, the seedlings were thinned to six per pot. The plants were then grown in a greenhouse at temperatures between 25 and $30^{\circ} \mathrm{C}$. The pakchoi was harvested two months after seed germination.

\section{Metal Analysis}

After harvesting, plant roots were carefully removed from each pot, and the shoots and roots were washed using deionized water to wash away adhering soil particles. The shoots and roots were then placed in an oven to dry at 
Table 2. Pot experiment treatments.

\begin{tabular}{|c|l|l|}
\hline Treatment & \multicolumn{1}{|c|}{ Material added Amount $(\mathrm{g} / \mathrm{kg})$} \\
\hline Control & Only soil and fertilizer & - \\
\hline H1 & Hydroxyapatite & 15 \\
\hline H2 & Hydroxyapatite & 30 \\
\hline H3 & Hydroxyapatite and humic acid & 15 hydroxyapatite +10 humic acid \\
\hline H4 & Hydroxyapatite and humic acid & 30 hydroxyapatite +20 humic acid \\
\hline N1 & Nano particle Hydroxyapatite & 15 \\
\hline N2 & Nano particle Hydroxyapatite & 30 \\
\hline N3 & Nano particle Hydroxyapatite and humic acid & 15 Nano particle Hydroxyapatite +10 humic acid \\
\hline N4 & Nano particle Hydroxyapatite and humic acid & 30 Nano particle Hydroxyapatite +20 humic acid \\
\hline S1 & Sepiolite & 15 \\
\hline S2 & Sepiolite & 30 \\
\hline S3 & Sepiolite and humic acid & 15 Sepiolite +10 humic acid \\
\hline S4 & Sepiolite and humic acid & 30 Sepiolite +20 humic acid \\
\hline HA1 & Humic acid & 10 \\
\hline HA2 & Humic acid & 20 \\
\hline
\end{tabular}

$60^{\circ} \mathrm{C}$ for 72 hours. Then the pakchoi were cut into shoot and root parts, and their dry weights were recorded. To measure $\mathrm{Pb}, \mathrm{Cd}$, and $\mathrm{Zn}$ concentrations in pakchoi tissues, plant samples were digested in a $15 \mathrm{ml} \mathrm{HNO}_{3}$ and $\mathrm{HClO}_{4}$ solution until the color became clear. At that point, the samples were filtered, reconstituted to the desired volume, and then tested using ICP-OES for $\mathrm{Pb}, \mathrm{Cd}$, and $\mathrm{Zn}$ concentrations.

\section{pH Determination and Sequential Extraction of Soil Samples}

After plants were harvested, a composite soil sample was taken from each pot. Soil $\mathrm{pH}$ was determined with a soil-to-deionized-water ratio of 1:2.5 (w/v) using a combination $\mathrm{pH}$ electrodes.

A sequential extraction procedure developed by BCR (European Community Bureau of Reference) was used in this experiment [20]. Each chemical fraction was operationally defined as follows:

1. Acid-soluble fraction: $40 \mathrm{ml} 0.1 \mathrm{~mol} \cdot \mathrm{L}^{-1} \mathrm{HOAc}$ was added to a $100-\mathrm{mL}$ centrifuge tube containing $1.000 \mathrm{~g}$ dried soil. The tube was shaken for $16 \mathrm{~h}$ using a mechanical shaker. After equilibration, the supernatant was centrifuged at 4,000 rpm for $10 \mathrm{~min}$. The supernatant was filtered through a $0.45 \mu \mathrm{m}$ filter, transferred into a polyethylene container, and stored at $4^{\circ} \mathrm{C}$ until analysis.

2. Reducible fraction: The residue from the acid-soluble fraction was extracted with $40 \mathrm{~mL} 0.5 \mathrm{~mol} \cdot \mathrm{L}^{-1} \mathrm{NH}_{2} \mathrm{OH}$ $\mathrm{HCl}$ ( $\mathrm{pH}$ of 1.5). The tube was shaken for $16 \mathrm{~h}$, and the extraction procedure from step 1 was performed.
3. Oxidizable fraction: The residue from the reducible fraction was extracted with $10 \mathrm{~mL} \mathrm{H}_{2} \mathrm{O}_{2}$ for $1 \mathrm{~h}$ at $85^{\circ} \mathrm{C}$, with an additional $10 \mathrm{~mL} \mathrm{H}_{2} \mathrm{O}_{2}$ for $1 \mathrm{~h}$ at $85^{\circ} \mathrm{C}$. Then, $50 \mathrm{~mL} 1 \mathrm{~mol} \cdot \mathrm{L}^{-1} \mathrm{NH}_{4} \mathrm{Ac}$ was added, the sample was shaken for $16 \mathrm{~h}$, and the extraction procedure from step 1 was performed.

4. Residual fraction: The residue from the oxidizable fraction was digested with mixed acid composed of $\mathrm{HNO}_{3}$ $\mathrm{HClO}_{4}$ - $\mathrm{HF}$.

After each extraction, separation was performed using a centrifuge at 10,000 rpm for $20 \mathrm{~min}$. Metal concentrations in the soil solutions were determined using ICP-OES.

\section{Statistical Analysis}

Microsoft Excel 2003 was used to calculate means and standard deviations (SD). Statistical analysis, including the analysis of variance, was conducted using SPSS Version 17.0 software (SPSS Inc., USA). Differences between means were determined using the Duncan test, with a significance level of $\mathrm{p}<0.05$. Figures were plotted using Origin 7.5 .

\section{Results and Discussion}

\section{Effects of Different Treatments on Soil $\mathrm{pH}$}

Fig. 1 shows the effects of chemical treatments on soil $\mathrm{pH}$. Soil $\mathrm{pH}$ increased with increased treatment levels. At lower treatment levels (H1, H3, N1, N3, S1, S3, and HA1), $\mathrm{pH}$ was incrementally higher than the control by 0.22 to 


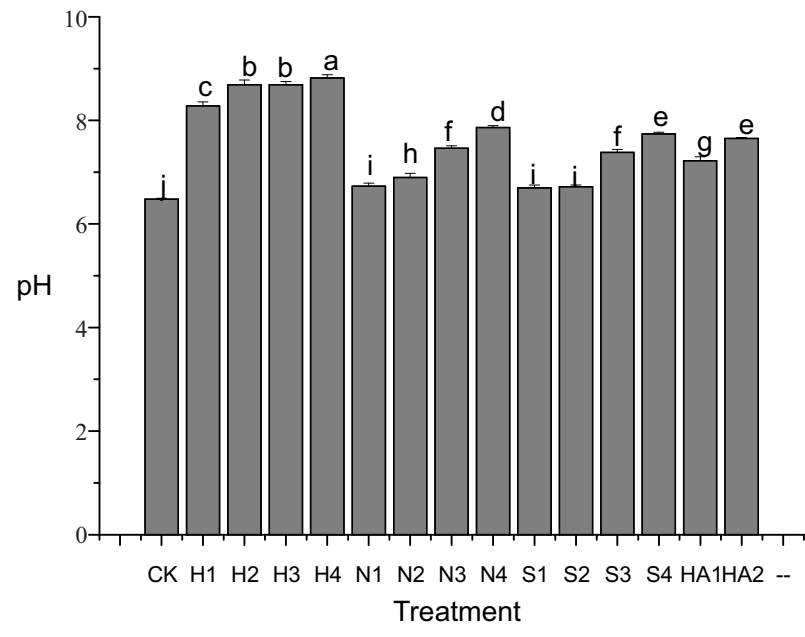

Fig. 1. Effects of different treatments on soil $\mathrm{pH}$. Bars with the same letter are not significantly different, $\mathrm{P}<0.05$.

2.21. At higher treatment levels $(\mathrm{H} 2, \mathrm{H} 4, \mathrm{~N} 2, \mathrm{~N} 4, \mathrm{~S} 2, \mathrm{~S} 4$ and HA2), $\mathrm{pH}$ was incrementally higher than the control by 0.24 to 2.34. Applying both natural minerals and humic acid-enhanced soil $\mathrm{pH}$ more than that when using a single amendment. For example, when using natural minerals without humic acid (H1, H2, N1, N2, S1 and S2), the soil $\mathrm{pH}$ increased by 0.22 to 2.21 units compared to the control. After supplementing natural minerals with humic acid $(\mathrm{H} 3$, $\mathrm{H} 4, \mathrm{~N} 3, \mathrm{~N} 4, \mathrm{~S} 3$, and S4), soil $\mathrm{pH}$ increased by 0.90 to 2.34 .

These results confirmed that natural minerals coapplied with humic acid showed more efficiency in increasing soil pH. Fig. 1 shows that the $\mathrm{H} 4$ treatment level increased soil $\mathrm{pH}$ the most among all amendments, increasing soil $\mathrm{pH}$ by 2.34 units compared to the control. This result corresponds with the results of Cui [8], who reported that supplemental hydroxyapatite can enhance soil $\mathrm{pH}$, and that the incremental increase is consistent with the amount of hydroxyapatite added. Treatment N4 also experienced an increase in soil $\mathrm{pH}$, by 1.38 units. Due to the alkalinity properties of sepiolite [1], Treatment S4 experienced a soil pH increase of 1.26 units. For treatment HA2, the soil $\mathrm{pH}$ was increased by 1.17 units.

\section{Sequential Extraction of $\mathrm{Pb}, \mathrm{Cd}$, and $\mathrm{Zn}$ in Soils}

BCR is one of the sequential extraction schemes established by the European Community Bureau of Reference, and is a standard method for comparing and evaluating metals in soil. Using this method, extracted metal concentrations in contaminated soil samples can be compared and evaluated using the sequential extraction of different forms of metal in soil. This includes the acid-soluble fraction (weakly bound with organic matter and carbonate fraction), reducible fraction (iron and manganese oxides fraction), oxidizable fraction (organically bound and sulfide fraction), and residual fraction [21]. Non-residual metals, which consist of the acid-soluble fraction, reducible fraction, and oxidizable fraction, are more mobile and bioavailable than the residual fraction. As such, the effectiveness of in situ remediation of metals-contaminated soils can be calculated using a fraction scheme. The more effective amendments transform greater amounts of metal from the non-residual to the residual fraction.

Fig. 2a shows the proportions of four fractions of $\mathrm{Pb}$. In untreated soil, most of the $\mathrm{Pb}$ was strongly associated with the reducible fraction, followed by the residual fraction, which was larger than the acid-soluble fraction. All the amendments were able to partition $\mathrm{Pb}$ from the non-residual fraction to the residual fraction, indicating that all amendments consistently decreased $\mathrm{Pb}$ mobility and bioavailability. The mHAP and nHAP transferred most of the $\mathrm{Pb}$ 's reducible fraction, acid-soluble fraction, and oxida-
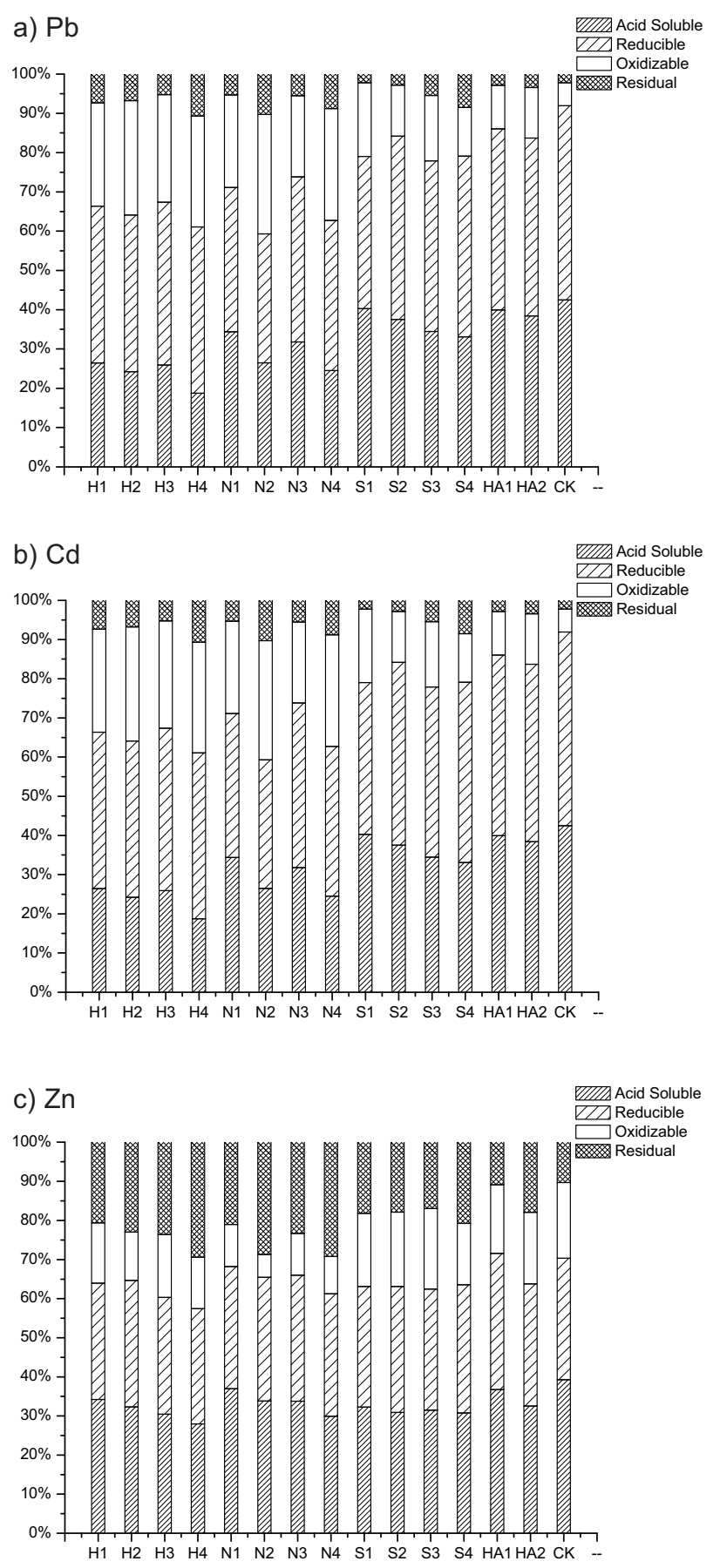

Fig. 2. Relative percentages of $\mathrm{Pb}, \mathrm{Cd}$, and $\mathrm{Zn}$ fractions in soils from $\mathrm{CK}$ and with various amendment treatments. 
Table 3. Concentrations of $\mathrm{Pb}, \mathrm{Cd}$, and $\mathrm{Zn}$ in pakchoi shoots and roots with different treatments $\left(\mathrm{mg} \cdot \mathrm{kg}^{-1} \mathrm{DW}\right)$.

\begin{tabular}{|c|c|c|c|c|c|c|}
\hline Treatment & $\mathrm{Pb}$ in shoots & $\mathrm{Pb}$ in roots & $\mathrm{Cd}$ in shoots & $\mathrm{Cd}$ in roots & $\mathrm{Zn}$ in shoots & $\mathrm{Zn}$ in roots \\
\hline Control & $16.43 \pm 2.54^{\mathrm{a}}$ & $58.52 \pm 4.06^{\mathrm{a}}$ & $4.17 \pm 0.30^{\mathrm{a}}$ & $9.63 \pm 1.14^{\mathrm{a}}$ & $23.39 \pm 2.69^{\mathrm{a}}$ & $58.24 \pm 5.06^{\mathrm{a}}$ \\
\hline H1 & $6.26 \pm 0.36^{\mathrm{def}}$ & $19.66 \pm 3.26^{\mathrm{ef}}$ & $1.65 \pm 0.18^{\mathrm{def}}$ & $3.00 \pm 0.41^{\mathrm{h}}$ & $16.69 \pm 3.67^{\mathrm{dfg}}$ & $26.96 \pm 4.08^{\mathrm{fg}}$ \\
\hline $\mathrm{H} 2$ & $5.40 \pm 1.04^{\mathrm{ef}}$ & $14.13 \pm 0.82^{\mathrm{ghi}}$ & $1.36 \pm 0.20^{\mathrm{f}}$ & $2.25 \pm 0.16^{\mathrm{i}}$ & $14.40 \pm 2.53^{\mathrm{ghi}}$ & $18.47 \pm 1.71^{\mathrm{i}}$ \\
\hline $\mathrm{H} 3$ & $5.14 \pm 0.63^{\mathrm{fg}}$ & $15.89 \pm 2.71^{\mathrm{gh}}$ & $1.43 \pm 0.19^{\text {ef }}$ & $2.67 \pm 0.24^{\mathrm{hi}}$ & $15.68 \pm 1.88^{\mathrm{dfgh}}$ & $21.61 \pm 2.86^{\text {ghi }}$ \\
\hline $\mathrm{H} 4$ & $4.50 \pm 0.39^{f}$ & $13.09 \pm 1.69^{\mathrm{i}}$ & $0.94 \pm 0.22^{g}$ & $2.06 \pm 0.25^{\mathrm{i}}$ & $11.05 \pm 1.63^{\mathrm{i}}$ & $16.33 \pm 1.80^{\mathrm{i}}$ \\
\hline N1 & $6.59 \pm 1.07^{\mathrm{ef}}$ & $19.11 \pm 1.63^{\text {ef }}$ & $2.25 \pm 0.16^{\mathrm{c}}$ & $4.27 \pm 0.21^{\mathrm{ef}}$ & $18.11 \pm 2.54^{\mathrm{cdfg}}$ & $36.11 \pm 2.53^{\text {cd }}$ \\
\hline N2 & $5.84 \pm 0.82^{\text {ef }}$ & $16.67 \pm 2.45^{\text {gh }}$ & $1.68 \pm 0.19^{\text {def }}$ & $3.83 \pm 0.16^{\mathrm{fg}}$ & $15.09 \pm 0.81^{\mathrm{fgh}}$ & $24.37 \pm 1.82^{\mathrm{gh}}$ \\
\hline N3 & $5.71 \pm 1.22^{\mathrm{ef}}$ & $17.83 \pm 2.29^{\mathrm{fg}}$ & $1.75 \pm 0.16^{\mathrm{de}}$ & $3.78 \pm 0.15^{\mathrm{fg}}$ & $17.87 \pm 2.12^{\text {cdfg }}$ & $30.14 \pm 2.56^{\text {ef }}$ \\
\hline N4 & $5.56 \pm 0.41^{\mathrm{ef}}$ & $14.46 \pm 1.71^{\mathrm{hi}}$ & $1.34 \pm 0.11^{\mathrm{f}}$ & $3.28 \pm 0.33^{\mathrm{gh}}$ & $12.57 \pm 1.96^{\mathrm{hi}}$ & $21.32 \pm 3.43^{\mathrm{hi}}$ \\
\hline S1 & $11.09 \pm 1.63^{\mathrm{b}}$ & $30.87 \pm 3.51^{\mathrm{cd}}$ & $1.98 \pm 0.08^{\text {cd }}$ & $5.37 \pm 0.89^{\mathrm{cd}}$ & $19.61 \pm 2.62^{\mathrm{bcd}}$ & $46.53 \pm 5.88^{b}$ \\
\hline S2 & $10.13 \pm 0.10^{\mathrm{bc}}$ & $22.95 \pm 1.95^{\mathrm{e}}$ & $1.83 \pm 0.19^{\mathrm{d}}$ & $5.13 \pm 0.43^{\mathrm{d}}$ & $18.57 \pm 2.68^{\text {bcdf }}$ & $36.51 \pm 2.77^{\mathrm{cd}}$ \\
\hline S3 & $8.71 \pm 2.04^{\mathrm{cd}}$ & $27.64 \pm 2.69^{\mathrm{d}}$ & $1.68 \pm 0.34^{\mathrm{def}}$ & $4.73 \pm 0.29^{\mathrm{de}}$ & $18.32 \pm 1.88^{\mathrm{cdfg}}$ & $40.01 \pm 4.08^{\mathrm{c}}$ \\
\hline S4 & $7.76 \pm 1.10^{\mathrm{de}}$ & $21.44 \pm 2.64^{\mathrm{e}}$ & $1.44 \pm 0.18^{\mathrm{ef}}$ & $4.20 \pm 0.12^{\mathrm{ef}}$ & $16.15 \pm 1.76^{\text {dgh }}$ & $33.38 \pm 1.80^{\text {de }}$ \\
\hline HA1 & $11.85 \pm 2.84^{\mathrm{b}}$ & $35.71 \pm 4.25^{\mathrm{b}}$ & $3.87 \pm 0.41^{\mathrm{a}}$ & $7.01 \pm 0.82^{b}$ & $22.32 \pm 3.53^{\mathrm{ab}}$ & $49.14 \pm 5.79^{b}$ \\
\hline HA2 & $10.42 \pm 0.98^{\mathrm{bc}}$ & $32.88 \pm 4.08^{\mathrm{bc}}$ & $2.72 \pm 0.17^{b}$ & $5.97 \pm 0.35^{\mathrm{c}}$ & $20.72 \pm 2.61^{\mathrm{abc}}$ & $46.11 \pm 3.35^{\mathrm{b}}$ \\
\hline
\end{tabular}

Data with a different letter in the same column indicate a statistically significant difference, according to the Duncan test. $\mathrm{P}<0.05$.

tive fraction to the residual fraction. Sepiolite and humic acid transformed a substantial amount of the acid-soluble fraction to the residual fraction.

The H4 treatment level showed the greatest effect in converting $\mathrm{Pb}$ from the non-residual to the residual fraction. The acid-soluble fraction portion decreased from $14.89 \%$ in the control to $1.91 \%$ in the $\mathrm{H} 4$ treatment soil, while the residual fraction increased from $32.67 \%$ in the control to $92.55 \%$ in the H4 treatment soil. The N4 treatment also reduced the $\mathrm{Pb}$ portion of acid-soluble fraction from $14.89 \%$ in the control to $2.49 \%$ in the treatment; the residual fraction increased from $32.67 \%$ to $89.64 \%$. In comparing the ability of $\mathrm{H} 4$ and $\mathrm{N} 4$ treatments to modify the $\mathrm{Pb}$ fraction distribution, the main difference was that a lower proportion of $\mathrm{Pb}$ 's acid-soluble fraction was found with $\mathrm{H} 4$ than with N4. The proportion of Pb's acid-soluble fraction was reduced from $14.89 \%$ in the control to $6.40 \%$ in the S4 treatment level. Meanwhile, the residual fraction increased from $32.67 \%$ to $46.29 \%$. The HA2 treatment decreased Pb's acidsoluble fraction from $14.89 \%$ to $8.21 \%$, and increased the residual fraction of $\mathrm{Pb}$ from $32.67 \%$ to $41.40 \%$.

Fig. $2 b$ shows the proportions of the four fractions of $\mathrm{Cd}$. In the control samples, $\mathrm{Cd}$ was predominantly in reducible and acid-soluble forms, indicating that a substantial fraction of $\mathrm{Cd}$ may be available for the plant. The residual fraction was the smallest portion of four fractions. All the amendments altered $\mathrm{Cd}$ distribution. The amendments mHAP and nHAP reduced a large amount of the reducible and acid-soluble fractions and enhanced the oxidative and residual fractions in contaminated soil. Sepiolite and humic acid slightly decreased the reducible and acid-soluble fractions and raised the amount of oxidative and residual fractions. The $\mathrm{H} 4$ treatment greatly decreased acid-soluble $\mathrm{Cd}$ and increased the oxidative fraction. This suggests that the HAP mechanism for the $\mathrm{Cd}$ reaction may be different from that of $\mathrm{Pb}$. The acid-soluble fraction of Cd was significantly reduced from $42.50 \%$ in the control to $18.74 \%$ with the $\mathrm{H} 4$ treatment, and to $24.51 \%$ with the N4 treatment. The S4 treatment changed the $\mathrm{Cd}$ distribution from the acid solution fraction to the oxidative and residual fractions. With the S4 treatment, the portion of acid solution fraction was reduced from $42.50 \%$ in the control to $33.09 \%$, and the residual fraction increased from $2.21 \%$ to $8.54 \%$. Adding HA2 reduced $42.50 \%$ of the acidsoluble fraction to $38.43 \%$.

Fig. 2c shows the proportions of the four fractions of $\mathrm{Zn}$. Similarly to $\mathrm{Cd}$, the $\mathrm{Zn}$ in the control samples was mainly comprised of reducible and acid-soluble fractions, followed by the oxidative fraction, which was larger than the residual fraction. Amendment treatments altered the partitioning of the $\mathrm{Zn}$ fraction. The mHAP and nHAP reduce the proportion of acid solution and oxidative fraction, increase the residual fraction, and slightly decrease the reducible fraction. Sepiolite and humic acid appear to reduce the acid solution fraction and increase the residual fraction. The $\mathrm{H} 4$ treatment was the most effective in decreasing the $\mathrm{Zn}$ acid solution fraction and increasing the residual fraction. When compared to untreated soil, the treatments resulted in a reduction of the $\mathrm{Zn}$ acid-soluble fraction portion in a range from $39.28 \%$ to $28.01 \%$; the $\mathrm{Zn}$ residual fraction ranged from $10.30 \%$ to $29.39 \%$ after the H4 treatment. 
Table 4. Shoot and root biomass of pakchoi (Brassia chinensis L.) with different treatments.

\begin{tabular}{|c|c|c|}
\hline \multirow{2}{*}{ Treatment } & Shoot & Root \\
\cline { 2 - 3 } & \multicolumn{2}{|c|}{$\left(\mathrm{g} \cdot \mathrm{pot}^{-1} \mathrm{DW}\right)$} \\
\hline Control & $1.25 \pm 0.06^{\mathrm{i}}$ & $0.24 \pm 0.01^{\mathrm{h}}$ \\
\hline H1 & $4.44 \pm 0.39^{\text {cd }}$ & $0.64 \pm 0.02^{\mathrm{d}}$ \\
\hline H2 & $5.60 \pm 0.28^{\mathrm{b}}$ & $0.99 \pm 0.07^{\mathrm{b}}$ \\
\hline H3 & $4.65 \pm 0.30^{\text {cd }}$ & $0.87 \pm 0.08^{\mathrm{b}}$ \\
\hline H4 & $6.03 \pm 0.57^{\mathrm{a}}$ & $1.05 \pm 0.04^{\mathrm{a}}$ \\
\hline N1 & $3.50 \pm 0.14^{\mathrm{e}}$ & $0.40 \pm 0.02^{\mathrm{f}}$ \\
\hline N2 & $4.34 \pm 0.25^{\mathrm{d}}$ & $0.44 \pm 0.03^{\mathrm{e}}$ \\
\hline N3 & $3.59 \pm 0.33^{\mathrm{e}}$ & $0.48 \pm 0.03^{\mathrm{de}}$ \\
\hline N4 & $4.77 \pm 0.29^{\mathrm{c}}$ & $0.57 \pm 0.06^{\mathrm{b}}$ \\
\hline S1 & $2.36 \pm 0.17^{\mathrm{g}}$ & $0.29 \pm 0.01^{\mathrm{f}}$ \\
\hline S2 & $3.09 \pm 0.23^{\mathrm{f}}$ & $0.39 \pm 0.03^{\mathrm{f}}$ \\
\hline S3 & $2.85 \pm 0.15^{\mathrm{f}}$ & $0.39 \pm 0.05^{\mathrm{c}}$ \\
\hline S4 & $3.66 \pm 0.25^{\mathrm{e}}$ & $0.45 \pm 0.02^{\mathrm{b}}$ \\
\hline HA1 & $1.80 \pm 0.29^{\mathrm{h}}$ & $0.31 \pm 0.02^{\mathrm{f}}$ \\
\hline HA2 & $2.18 \pm 0.19^{\mathrm{g}}$ & $0.36 \pm 0.02^{\mathrm{f}}$ \\
\hline
\end{tabular}

Data with a different letter in the same column indicate a statistically significant difference, according to the Duncan test; $\mathrm{P}<0.05$.

In addition, it was found that $\mathrm{H} 1$ to $\mathrm{H} 4$ treatments were more effective in shifting the non-residual fractions to the residual fractions than other treatment types. This indicates that hydroxyapatite (especially when co-applied with humic acid) is suitable for use with $\mathrm{Zn}$-contaminated soil. N4 and S4 also decreased the acid-soluble fraction and increased the residual fraction, the reductions were 9.33\% for N4 and $8.53 \%$ for S4 for the acid-soluble fraction, and the increments were $18.91 \%$ for N4 and $10.45 \%$ for S4 for the residual fraction. This indicates that both N4 and S4 have the ability to transform the higher bio-availability fraction of $\mathrm{Zn}$ to a lower bio-availability form, immobilizing $\mathrm{Zn}$ in contaminated soil. HA2 translocated the acid-soluble fraction of $\mathrm{Zn}$ from $39.28 \%$ in the control to $32.53 \%$ in the treatment and slightly increased the residual fraction.

In this study, a higher concentrated treatment usually resulted in a significantly lower concentration of non-residual $\mathrm{Pb}, \mathrm{Cd}$, and $\mathrm{Zn}$ than similar treatments at lower concentrations. When examining the $\mathrm{Pb}, \mathrm{Cd}$, and $\mathrm{Zn}$ fractions during sequential extraction, the co-remediation effect of mHAP, nHAP, and sepiolite with humic acid were more effective in decreasing $\mathrm{Pb}, \mathrm{Cd}$, and $\mathrm{Zn}$ mobility and bioavailability in the polluted soil when compared to single amendment remediation. H4 appeared to be the most effective treatment in transforming acid fractions of $\mathrm{Pb}, \mathrm{Cd}$, and $\mathrm{Zn}$ into the residual fraction, suggesting that $\mathrm{H} 4$ was most suitable for treating $\mathrm{Pb}$-, $\mathrm{Cd}$-, and $\mathrm{Zn}$-contaminated soil. This opens new options for researching the co-remediation of heavy metal-contaminated soil, and for applying natural minerals in environmental remediation.

\section{Effects of Different Amendments on the Uptake of $\mathrm{Pb}, \mathrm{Cd}$, and $\mathrm{Zn}$ by Pakchoi}

Table 3 provides $\mathrm{Pb}, \mathrm{Cd}$, and $\mathrm{Zn}$ concentrations in pakchoi shoots and roots, and show that amendments greatly decreased $\mathrm{Pb}, \mathrm{Cd}$, and $\mathrm{Zn}$ levels in the plant compared to the control. At the lower treatment levels (H1, H3, N1, N3, $\mathrm{S} 1, \mathrm{~S} 3$, and $\mathrm{HA} 1), \mathrm{Pb}, \mathrm{Cd}$, and $\mathrm{Zn}$ concentrations in the shoots were reduced by $27.9-68.7 \%$ for $\mathrm{Pb}$, by $7.2-65.7 \%$ for $\mathrm{Cd}$, and by $4.6-32.9 \%$ for $\mathrm{Zn}$. Meanwhile, $\mathrm{Pb}, \mathrm{Cd}$, and $\mathrm{Zn}$ concentrations in the roots were reduced by $38.9-72.8 \%$ for $\mathrm{Pb}$, by $27.2-72.2 \%$ for $\mathrm{Cd}$, and by $15.6-62.9 \%$ for $\mathrm{Zn}$.

With the higher treatment levels $(\mathrm{H} 2, \mathrm{H} 4, \mathrm{~N} 2, \mathrm{~N} 4, \mathrm{~S} 2$, $\mathrm{S} 4$, and $\mathrm{HA} 2$ ), the $\mathrm{Pb}, \mathrm{Cd}$, and $\mathrm{Zn}$ concentrations in the shoots decreased by $36.6-72.6 \%$ for $\mathrm{Pb}, 34.8-77.4 \%$ for $\mathrm{Cd}$, and $11.4-52.8 \%$ for $\mathrm{Zn}$. In the meantime, $\mathrm{Pb}, \mathrm{Cd}$, and $\mathrm{Zn}$ concentrations in the roots were reduced by $43.8-77.6 \%$ for $\mathrm{Pb}, 38.0-78.6 \%$ for $\mathrm{Cd}$, and $20.8-71.9 \%$ for $\mathrm{Zn}$, compared to the control. These results indicate that increasing amendment application rates may restrain the amount of $\mathrm{Pb}, \mathrm{Cd}$, and $\mathrm{Zn}$ used by pakchoi.

Co-applying natural minerals with humic acid reduced more $\mathrm{Pb}, \mathrm{Cd}$, and $\mathrm{Zn}$ in pakchoi than with one amendment alone. When treated with natural minerals with humic acid (H3, H4, N3, N4, S3, and S4), the Pb, Cd, and Zn in pakchoi shoots were inhibited by $46.9-72.6 \%$ for $\mathrm{Pb}, 59.7$ $77.4 \%$ for $\mathrm{Cd}$, and $21.6-52.8 \%$ for $\mathrm{Zn}$. For roots, the reductions were $52.8-77.6 \%$ for $\mathrm{Pb}, 50.9-78.6 \%$ for $\mathrm{Cd}$, and 31.3 $71.9 \%$ for $\mathrm{Zn}$, in contrast to the control. When the amendment was used alone ( $\mathrm{H} 1, \mathrm{H} 2, \mathrm{~N} 1, \mathrm{~N} 2, \mathrm{~S} 1$, and S2), Pb, Cd, and $\mathrm{Zn}$ in pakchoi shoots were $32.4-67.1 \%, 46.0-67.3 \%$, and $16.1-38.4 \%$, respectively. The reductions in roots for the three metals were $47.2-75.9 \%, 44.2-76.6 \%$, and 20.1$68.3 \%$, respectively, compared to that of control.

The $\mathrm{H} 4$ treatment was the most efficient at reducing $\mathrm{Pb}$, $\mathrm{Cd}$, and $\mathrm{Zn}$ uptake by the plant. After applying $\mathrm{H} 4, \mathrm{~Pb}, \mathrm{Cd}$, and $\mathrm{Zn}$ concentrations decreased by $72.6 \%, 77.5 \%$, and $52.8 \%$ for shoots, and $77.6 \%, 78.6 \%$, and $72.0 \%$ for roots. $\mathrm{Pb}, \mathrm{Cd}$, and $\mathrm{Zn}$ in shoots and roots decreased significantly when the $\mathrm{N} 4$ treatment was added. $\mathrm{Pb}, \mathrm{Cd}$, and $\mathrm{Zn}$ was reduced by $66.1 \%, 67.9 \%$, and $46.3 \%$ for shoots, and $75.3 \%$, $65.9 \%$, and $63.4 \%$ for roots, compared with untreated soil. Amending soils with $\mathrm{S} 4$ led to a significant reduction in $\mathrm{Pb}$, $\mathrm{Cd}$, and $\mathrm{Zn}$ uptake into pakchoi shoots and roots: $52.8 \%$ for $\mathrm{Pb}, 65.5 \%$ for $\mathrm{Cd}$, and $30.9 \%$ for $\mathrm{Zn}$ decrease in shoots; $63.4 \%$ for $\mathrm{Pb}, 56.4 \%$ for $\mathrm{Cd}$, and $42.7 \%$ for $\mathrm{Zn}$ decrease in roots, when compared to control. HA2 was less effective than the treatments discussed above, reducing $\mathrm{Pb}, \mathrm{Cd}$, and $\mathrm{Zn}$ in the pakchoi shoots by $36.6 \%, 34.8 \%$, and $11.4 \%$, and by $43.8 \%, 38.0 \%$, and $20.8 \%$, respectively, in the roots.

\section{Effects of Amendments on Pakchoi Biomass}

The inhibitory effects on amendments on plant biomass provide an index of phytotoxicity; a biomass increase as a result of amendment application could predict a toxicity 
reduction [22]. Results in Table 4 demonstrate that all amendments significantly increased pakchoi shoot and root biomass. Furthermore, shoot and root biomass consistently increased with an increased treatment level. At lower treatment levels (H1, H3, N1, N3, S1, S3, and HA1), shoot yield was 0.43 to 2.71 times the control's yields; root yields were 0.21-2.63 times the control. At higher treatment levels (H2, H4, N2, N4, S2, S4, and HA2), shoot yield enhancement was 0.74-3.81 times the control, and root yields were 0.503.38 times the control.

Further, compared to the single amendment treatment, the co-application of the natural minerals mixed with humic acid enhanced shoot and root biomass. For example, after applying natural minerals with humic acid $(\mathrm{H} 3, \mathrm{H} 4, \mathrm{~N} 3$, $\mathrm{N} 4, \mathrm{~S} 3$, and S4), shoot biomass increased by 1.27-3.81fold, and root biomass increased by 0.63 -3.38-fold, compared with the control. When the natural minerals were applied without humic acid (H1, H2, N1, N2, S1, and S2), shoot biomass incremental growth was by 0.88 -3.47-fold and the root biomass growth was $0.21-3.13$-fold. These results demonstrate that co-applying natural minerals with humic acid was more efficient than a single natural minerals treatment in increasing pakchoi biomass.

In this study, the lower pakchoi biomass in the control may be due to low soil $\mathrm{pH}$ and high metal toxicity. Chemical amendments can promote plant growth by increasing soil $\mathrm{pH}$; decreasing the bioavailable fraction of $\mathrm{Pb}, \mathrm{Cd}$, and $\mathrm{Zn}$; and enhancing pakchoi biomass. In addition, as an organic fertilizer, humic acid offers nutrition for the pakchoi and boosts shoot and root development [17]. Among all the amendments, the $\mathrm{H} 4$ treatment level exhibited the best effect in increasing pakchoi shoot and root biomass. When treated with H4, pakchoi shoot and root biomass increased by 3.81 and 3.38 times, respectively, compared with the control. The N4 treatment level enhanced pakchoi shoot and root biomass by 2.81 and 1.38 times, compared with untreated soil. Further supplementing the plant with S4 promotes pakchoi growth by increasing the yield by 1.92 times for the shoot and 0.88 times for the root. Applying HA2, the increment of shoots and roots yield was $74.0 \%$ and $50.0 \%$, compared to the control. Among the four treatments (H4, N4, S4, and HA2), the H4 treatment showed the best effect in increasing plant shoot and root yield, followed by N4. The HA2 treatment has the least effect on plant growth. These results are consistent with the decreased $\mathrm{Pb}, \mathrm{Cd}$, and $\mathrm{Zn}$ concentrations in plant shoots and roots, and confirmed that the amendments both alleviated heavy metal phytotoxicity and benefitted pakchoi growth.

Precipitates such as metal carbonates, hydroxides and metal-organic complexes, are more likely to form at high $\mathrm{pH}$ conditions [23]. The increase in soil $\mathrm{pH}$ results in more negatively charged sorption sites on the soil colloid and organic matter surfaces, decreasing metal bio-availability $[24,25]$. In this study, the supplemental hydroxyapatite treatment can increase soil $\mathrm{pH}$ and reduce metal bioavailability. Bolisson [26] demonstrated the mechanism by which hydroxyapatite increases soil $\mathrm{pH}$, finding that the dissolution of hydroxyapatite in soil can consume $\mathrm{H}^{+}$. The reaction is as follows:

$$
\mathrm{Ca}_{10}\left(\mathrm{PO}_{4}\right)_{6}(\mathrm{OH})_{2}+14 \mathrm{H}^{+}=10 \mathrm{Ca}^{2+}+6 \mathrm{H}_{2} \mathrm{PO}_{4}^{-}+2 \mathrm{H}_{2} \mathrm{O}
$$

Furthermore, hydroxyapatite can react with $\mathrm{F}^{-}$in soil to form $\mathrm{Ca}_{10}\left(\mathrm{PO}_{4}\right)_{6} \mathrm{~F}_{2}$, which is insoluble in the soil. As a result, more $\mathrm{H}^{+}$can be consumed and soil $\mathrm{pH}$ increases [27]. In this study, mHAP increased soil $\mathrm{pH}$ values more effectively than nHAP. This may be due to the fact that nanomaterials can easily aggregate, changing their surface sorption and migration properties, and decreasing their dissolution rates [28]. Micrometer HAP has larger particles than nanometer HAP, and is therefore easier to dissolve in the soil. As such, the larger dissolution rate of mHAP may drive the increased $\mathrm{pH}$ phenomenon [8]. Results also showed that adding sepiolite can increase $\mathrm{pH}$ in contaminated soil. This is because sepiolite contains a high percentage of calcium carbonate, giving it alkaline properties $[1,9]$.

There are several reasons explaining the hydroxyapatite remediation effects on $\mathrm{Pb}$-contaminated soil. Adsorption, desorption, precipitation, rhizosphere modification, and physiological reactions reduce $\mathrm{Pb}$ mobility and bioavailability. However, a key $\mathrm{Pb}$ immobilization process involving hydroxyapatite is the formation of pyromorphite, or other compounds with low solubility. This is associated with the transfer of large amounts of $\mathrm{Pb}$ from the non-residual to residual fractions [29, 30]. This study confirmed that hydroxyapatite amendments significantly increased the residual fraction of $\mathrm{Pb}$ in soils, consistent with the reduction of $\mathrm{Pb}$ concentration in plant shoots and roots. Hydroxyapatite also modified $\mathrm{Cd}$ and $\mathrm{Zn}$ distribution in soil, increasing residual $\mathrm{Cd}$ and $\mathrm{Zn}$ while decreasing nonresidual $\mathrm{Cd}$ and $\mathrm{Zn}$. $\mathrm{Cd}$ and $\mathrm{Zn}$ immobilization with hydroxyapatite had different mechanisms than with $\mathrm{Pb}$. As Chen [11] noted, the reduction in $\mathrm{Cd}$ and $\mathrm{Zn}$ acid-soluble fractions with hydroxyapatite can be attributed to sorption to the hydroxyapatite surface, rather than by insoluble compound formation. Furthermore, increased $\mathrm{pH}$ values caused by hydroxyapatite in contaminated soils may lead to the formation of $\mathrm{Cd}(\mathrm{OH})_{2}$ and $\mathrm{Zn}(\mathrm{OH})_{2}$. This results in a large amount of $\mathrm{Cd}(\mathrm{OH})_{2}$ and $\mathrm{Zn}(\mathrm{OH})_{2}$ precipitation [2].

Sepiolite is a natural hydrated magnesium silicate mineral, with the ability to reduce heavy metals bioavailability in soils and inhibit trace element absorption in plants. Many researchers have focused on its use [1, 7]. Liang [9] used sepiolite as an amendment to remediate Cd-contaminated paddy soil. Their study showed that applying sepiolite can increase paddy soil $\mathrm{pH}$, while reducing exchangeable $\mathrm{Cd}$ concentrations. The main immobilization mechanisms for sepiolite include: precipitation of $\mathrm{Cd}$ as carbonates or hydroxides, and surface complexation. Sun [7] investigated the remediation effects of sepiolite on soils artificially polluted with cadmium. Results indicated that adding sepiolite can increase soil $\mathrm{pH}$ and decrease the extractable $\mathrm{Cd}$ concentration. Moreover, applying sepiolite significantly restricted $\mathrm{Cd}$ uptake in spinach shoots grown in Cd-contaminated soil. In this study, sepiolite effectively shifted heavy metal fractions from non-residual to residual fractions, and reduced $\mathrm{Pb}, \mathrm{Cd}$, and $\mathrm{Zn}$ uptake in pakchoi. This result is consistent with Sun [1] and Liang [9]. 
However, when compared with hydroxyapatite and sepiolite, hydroxyapatite appears to be more effective than sepiolite in immobilizing $\mathrm{Pb}, \mathrm{Cd}$, and $\mathrm{Zn}$, and in inhibiting heavy metal uptake by pakchoi. For instance, compared to the control, when treated with $\mathrm{S} 4$, the acid-soluble fraction decreased by $8.49 \%$ for $\mathrm{Pb}, 9.41 \%$ for $\mathrm{Cd}$, and $8.35 \%$ for $\mathrm{Zn}$. The incremental residual fraction was $13.62 \%, 6.33 \%$, and $10.45 \%$ for $\mathrm{Pb}, \mathrm{Cd}$, and $\mathrm{Zn}$, respectively. For hydroxyapatite, $\mathrm{H} 4$ treatment led to a reduction of the acid-soluble fraction by $12.98 \%$ for $\mathrm{Pb}, 23.76 \%$ for $\mathrm{Cd}$, and $11.27 \%$ for $\mathrm{Zn}$. The incremental residual fraction was $59.88 \%, 8.52 \%$ and $19.09 \%$ for $\mathrm{Pb}, \mathrm{Cd}$, and $\mathrm{Zn}$, respectively. Larger $\mathrm{pH}$ values found in hydroxyapatite-treated soil may help explain this phenomenon. The $\mathrm{H} 4$ treatment increased $\mathrm{pH}$ value by 2.34 units, while the S4 treatment increased it by 1.26 units; the $\mathrm{pH}$ value increase was 2.21 and 0.24 units when treated with $\mathrm{H} 2$ and S2, respectively. Heavy metals stability was strongly $\mathrm{pH}$-dependent; mobility and solubility decreased with increasing $\mathrm{pH}$. Natural clays are considered to decrease metal mobility and solubility in contaminated soils by changing soil properties, especially $\mathrm{pH}$ [31]. Therefore, sepiolite impacted soil $\mathrm{pH}$ less than hydroxyapatite, at the same treatment rate. This resulted in less $\mathrm{Pb}, \mathrm{Cd}$, and $\mathrm{Zn}$ being immobilized.

This study found that adding humic acid can reduce the non-residual fraction of $\mathrm{Pb}, \mathrm{Cd}$, and $\mathrm{Zn}$, while increasing the residual fraction of $\mathrm{Pb}, \mathrm{Cd}$, and $\mathrm{Zn}$. This suggests that more available metal fractions in soil were changed into non-available fractions, with less taken up and used by pakchoi. This result was similar to findings by Tordoff [18]. The major benefits of humic acid when applied to soil are due to the incrementally increased organic matter content and biological activity. Acting as a nutrient pool, humic acid can improve soil physical properties and nutrient cycling, increase CEC and buffer capacity, and reduce compaction [16, 32]. Additionally, humic acid can decrease heavy metal bioavailability by translocating them from forms available to plants (such as acid-soluble fractions) to oxidizable and residual fractions. Further, adding humic acid to metals-contaminated soils has an improvement effect due to increased surface area and the enhanced number of specific adsorption sites on soil particles [33]. In addition, the reduction of $\mathrm{Pb}, \mathrm{Cd}$, and $\mathrm{Zn}$ in plants and non-residual fractions in soil with the increased application levels of mHAP, nHAP, and sepiolite after co-remediation with humic acid confirms that humic acid can improve remediation of $\mathrm{Pb}$-, $\mathrm{Cd}$-, and $\mathrm{Zn}$-contaminated soil. In other words, study results prove that humic acid assists mHAP, $\mathrm{nHAP}$, and sepiolite in enhancing and promoting $\mathrm{Pb}, \mathrm{Cd}$, and $\mathrm{Zn}$ immobilization in soil. Furthermore, the co-application of $30 \mathrm{~g} \cdot \mathrm{kg}^{-1}$ hydroxyapatite with $20 \mathrm{~g} \cdot \mathrm{kg}^{-1}$ humic acid showed the best effect on $\mathrm{Pb}, \mathrm{Cd}$, and $\mathrm{Zn}$ remediation.

Nanomaterials have a higher reactivity and greater adsorption ability, and some studies have suggested that nanomaterials are superior to traditional amendments using common particle sizes for soil remediation [15]. Theoretically, in this study, compared to mHAP, nHAP would immobilize a larger amount of $\mathrm{Pb}, \mathrm{Cd}$, and $\mathrm{Zn}$, likely due to its smaller particle size and larger surface area.
However, we noted that mHAP was more effective than nHAP in immobilizing $\mathrm{Pb}, \mathrm{Cd}$, and $\mathrm{Zn}$. Moreover, soil $\mathrm{pH}$ was more greatly enhanced by mHAP. Gilbert [28] and Cui [8] speculated that nanomaterials can easily aggregate, altering their surface sorption and migration ability while decreasing their dissolution rates. Compared to nHAP, mHAP has a larger particle size, making it much more difficult for mHAP to aggregate. Therefore, we hypothesize that the higher dissolution rate was the primary reason for the increased $\mathrm{pH}$ and for the increased immobilization effects. Further study is needed to verify this hypothesis.

\section{Conclusion}

Co-remediation, using the amendments studied here, increased pakchoi biomass and reduced $\mathrm{Pb}, \mathrm{Cd}$, and $\mathrm{Zn} \mathrm{lev-}$ els in pakchoi shoots and roots. In addition, soil $\mathrm{pH}$ increased and the bioavailable chemical fraction decreased, in alignment with increasing treatment levels. Across all treatments, co-applying $30 \mathrm{~g} \cdot \mathrm{kg}^{-1}$ hydroxyapatite with $20 \mathrm{~g} \cdot \mathrm{kg}^{-1}$ humic acid yielded the best results, indicating that these co-remediation amendments can be applied to $\mathrm{Pb}$-, Cd-, and Zn-contaminated soil. Co-remediation using micro particle hydroxyapatite, nano particle hydroxyapatite, and sepiolite with humic acid was more effective in inhibiting $\mathrm{Pb}, \mathrm{Cd}$, and $\mathrm{Zn}$ uptake in pakchoi and restraining $\mathrm{Pb}, \mathrm{Cd}$, and $\mathrm{Zn}$ availability in polluted soil, compared with remediation using a single amendment. Moreover, mHAP was superior to nHAP in immobilizing $\mathrm{Pb}, \mathrm{Cd}$, and $\mathrm{Zn}$ in metal-contaminated soil and reducing the $\mathrm{Pb}, \mathrm{Cd}$, and $\mathrm{Zn}$ by pakchoi. In conclusion, our study found that co-remediation using hydroxyapatite with humic acid may effectively treat $\mathrm{Pb}$-, $\mathrm{Cd}$-, and $\mathrm{Zn}$-contaminated soil, offering an improved approach for soil remediation.

\section{Acknowledgements}

This work was supported by the Funding of Hanshan Normal University (No. LF201402).

\section{References}

1. SUN Y.B., SUN G.H., XU Y.M., WANG L., LIANG X.F., LIN D.S. Assessment of sepiolite for immobilization of cadmium-contaminated soils. Geoderma, 193-194, 149, 2013.

2. CAO X.D., DERMATA S.D., XU X., SHEN G., Immobilization of lead in shooting rang soils by means of cement, quicklime, and phosphate amendments. Environ. Sci. Pollut. Res. 152, 184, 2008.

3. GARAU G., CASTALDI P., SANTONA L., DEIANA P., MELIS P. Influence of red mud, zeolite and lime on heavy metal immobilization, culturable heterotrophic microbial populations and enzyme activities in a contaminated soil. Geoderma, 142, (1-2), 47, 2007.

4. CHANG Y.T., HIS H.C., HSEU Z.Y., JHENG S.L. Chemical stabilization of cadmium in acidic soil using alkaline agronomic and industrial by-products. J. Environ. Sci. Heal. A, 48, (13), 1748, 2013. 
5. ZANUZZI A., FAZ A., ACOSTA J.A. Chemical stabilization of metals in the environment: a feasible alternative for remediation of mine soils. Environ. Earth Sci., 70, (6), 2626, 2013.

6. LI P., WANG X.X., ZHANG T.L., ZHOU D.M., HE Y.Q. Effects of several amendments on rice growth and uptake of copper and cadmium from a contaminated soil. J. Environ. Sci.-China, 20, 449, 2008.

7. SUN Y.B., SUN G.H., XU Y.M., WANG L., LIN D.S., LIANG X.F., SHI X. In situ stabilization remediation of cadmium contaminated soils of wastewater irrigation region using sepiolite. J. Environ. Sci.-China, 24, (10), 1799, 2012.

8. CUI H.B., ZHOU J., ZHAO Q.G., SI Y.B., MAO J.D., FANG G.D., LIANG J.N. Fractions of $\mathrm{Cu}, \mathrm{Cd}$ and enzyme activities in a contaminated soil as affected by applications of micro- and nanohydroxyapatite. J. Soil. Sediment, 13, (4), 742, 2013

9. $\quad$ LIANG X.F., HAN J., XU Y.M., SUN Y.B., WANG L., TAN $\mathrm{X}$. In situ field-scale remediation of $\mathrm{Cd}$ polluted paddy soil using sepiolite and palygorskite. Geoderma, 235, 9, 2014.

10. LI H., SHI W.Y., SHAO H.B., SHAO M.A. The remediation of the lead-polluted garden soil by natural zeolite. J. Hazard. Mater., 169, 1106, 2009.

11. CHEN S.B., XU M.G., MA Y.B., YANG J.C. Evaluation of different phosphate amendments on availability of metals in contaminated soil. Ecotox. Environ. Safe., 67, 278, 2007.

12. CHEN S.B., ZHU Y.G., MA Y.B., MCKAY G. Effect of bone char application on $\mathrm{Pb}$ bioavailability in a Pb-contaminated soil. Environ. Pollut., 139, 433, 2006.

13. LIU R.Q., ZHAO D.Y. Reducing leachability and bioaccessibility of lead in soils using a new class of stabilized iron phosphate nanoparticles. Water. Res., 41, (12), 2491, 2007.

14. LIU R.Q., ZHAO D.Y. In situ immobilization of $\mathrm{Cu}(\mathrm{II})$ in soils using a new class of iron phosphate nanoparticles. Chemosphere, 68, (10), 1867, 2007.

15. LIU R.Q., LAI R. Nanoenhanced materials for reclamation of mine lands and other degraded soils: a review. J. Nanotech., article ID 461468, 2012.

16. CHAIYARAT R., SUEBSIMA R., PUTWATTANA N., KRUATRACHUE M., POKETHITIYOOK P. Effects of soil amendments on growth and metal uptake by Ocimum gratissimum grown in $\mathrm{Cd} / \mathrm{Zn}$-contaminated soil. Water Air Soil Poll., 214, (1), 383, 2011.

17. SHI W.Y., SHAO H.B., LI H., SHAO M.A., DU S. Coremediation of the lead polluted garden soil by exogenous natural zeolite and humic acids. J. Hazard. Mater., 167, (13), 136, 2009.

18. TORDO G.M., BAKER A.J.M., WILLIS A.J. Current approaches to revelation and reclamation of metalliferous mine wastes. Chemosphere, 41, 219, 2000

19. LU R.K. Analytical methods for soils and agricultural chemistry, Beijing: Chinese agricultural science and technology Press, 1999.
20. RAURET G., RUBIO R., LOPEZ-SANCHEZ J.F. Optimization of Tessier procedure for metal solid speciation in river sediments. Trac-Trend Anal. Chem., 36, 69, 1989.

21. LIN D.S., ZHOU Q.X. Effects of soil amendments on the extractability and speciation of cadmium, lead and copper in a contaminated soil. B. Environ. Contam. Tox., 83, (1), 136, 2009.

22. FRIESL W., HORAK O., WENZEL W.W. Immobilization of heavy metals in soils using inorganic amendments in a greenhouse study. J. Plant Nutr. Soil Sc., 167, (1), 54, 2004.

23. GU H.H., QIU H., TIAN T., ZHAN S.S., DENG T.H.B., CHANEY R.L., WANG S.Z., TANG Y.T., MOREL J.L., QIU R.L. Mitigation effects of silicon rich amendments on heavy metal accumulation in rice (Oryza sativa L.,) planted on multi-metal contaminated acidic soil. Chemosphere 83, (9), 1234, 2011.

24. BOLAN N.S., MAKINO T., KUNHIKRISHNAN A., KIM P.J. ISHIKAWA S., MURAKAMI M., NAIDU R., KIRKHAM M.B. Cadmium contamination and its risk management in rice ecosystems. Adv. Agron., 119, 183, 2013.

25. PEHLIVAN E., OZKAN A.M., DINC S., PARLAYICI S. Adsorption of $\mathrm{Cu}^{2+}$ and $\mathrm{Pb}^{2+}$ ion on dolomite powder. $\mathrm{J}$. Hazard. Mater. 167, (1-3), 1044, 2009.

26. BOISSON J., RUTTENS A., MENCH M., VANGRONSVELD J. Evaluation of hydroxyapatite as a metal immobilizing soil additive for the remediation of polluted soils. Part 1. Influence of hydroxyapatite on metal exchangeability in soil, plant growth and plant metal accumulation. Environ. Pollut., 104, 225, 1999.

27. ESLAMI H., SOLATI-HASHJIN M., TAHRIRI M. Effect of fluorine ion addition on structural, thermal, mechanical, solubility and biocompatibility characteristics of hydroxyapatite nanopowders. Adv. Appl. Ceram., 109, 200, 2010.

28. GILBERT B., ONO R.K., CHING K.A., KIM C.S. The effects of nanoparticle aggregation processes on aggregate structure and metal uptake. J. Colloid Interf. Sci., 339, 285, 2009.

29. CAO R.X., MA L.Q., CHEN M., SINGH S.P., HARRIS W.G. Phosphate-induced metal immobilization in a contaminated site. Environ. Pollut., 122, (1), 19, 2003.

30. CHEN S.B., CHEN L., MA Y.B. Can phosphate compounds be used to reduce the plant uptake of $\mathrm{Pb}$ and resist the $\mathrm{Pb}$ stress in Pb-contaminted soils?. J. Environ. Sci., 21, 360, 2009.

31. WANG L., XU Y.M., LIANG X.F., SUN Y., QIN X. Effect and mechanism of immobilization of cadmium and lead compound contaminated soil using new hybrid material. J. Environ. Sci. -China, 32, 581, 2011.

32. STEWART B.A., ROBINSON C.A., PARKER D.B Examples and case studies of beneficial reuse of beef cattle by products. In W.A. Dick (Ed.). Land application of agricultural, industrial, and municipal by-products. Madison: soil science society of America, Inc, 2000.

33. SHUMAN L.M. Organic waste amendments effect on zinc fractions of two soils. J. Environ. Qual., 28, 1442, 1999. 
